\title{
The cooperative dynamics of Brazilian Oil and Gas Innovation System: A Research Proposal
}

\author{
Carlos Alexandre Ferreira Gama ${ }^{1}$, Adriana S Vivacqua ${ }^{1}$ \\ ${ }^{1}$ Programa de Pós-Graduação em Informática (PPGI) \\ Universidade Federal do Rio de Janeiro (UFRJ) \\ Rio de Janeiro - RJ - Brasil \\ cafgama@ufrj.br; avivacquaddcc.ufrj.br
}

\begin{abstract}
Brazilian legislation for the oil and gas sector stipulates a mandatory $R \& D$ investment for Oil and Gas Companies. This so-called Petroleum Law led to the establishment of an Innovation System between Universities, Government and Industry (UGI) in which relations between industry researchers and university professors are the heart of this system. From this perspective, modeling the social dynamics of researchers and professors could be considered a relevant contribution to understand the complex dynamic of this Innovation System. This article presents a research proposal to analyze and simulate the social dynamics of cooperation between researchers and professors through the Complex Adaptive Systems lens, in order to understand and measure the possible effects of the investment policy adopted by Brazilian government .
\end{abstract}

Resumo. A legislação brasileira para o setor de petróleo e gás prevê o investimento obrigatório em $P \& D$ para empresas exploradoras de petróleo e gás. A chamada Lei do Petróleo levou ao estabelecimento de um Sistema de Inovação entre Universidades, Governo e Indústria (UGI), no qual as relações entre pesquisadores da indústria e professores universitários são o coração deste sistema. Nessa perspectiva, a modelagem da dinâmica social entre pesquisadores e professores pode ser considerada uma contribuição relevante para a compreensão da dinâmica complexa deste Sistema de Inovação. Este artigo apresenta uma proposta de pesquisa para analisar e simular a dinâmica de cooperação entre pesquisadores e professores por meio da ótica de Sistemas Adaptativos Complexos, a fim de compreender e mensurar os possíveis efeitos da política de investimentos adotada pelo governo brasileiro.

\section{Introduction}

Technology-based industries generate wealth and economic development, reiterating technical progress as a source and strategy for sustainable economic growth. New technologies can lead to changes in the development trajectory of countries, with the creation of new markets, products and services, giving rise to a virtuous circle where technology is a major factor in the generation of wealth and development [Nelson and Winter 2014].

The relation among University-Government-Industry (UGI) has been studied in the scientific literature, primarily in the innovation domain, where models such as the Triple Helix (TH), National Innovation Systems (SNI) and hybrids were developed to 
describe the dynamics of this relationship [Ranga and Etzkowitz 2015] [fig.1]. In innovation systems, the innovation is the result of a non-linear, enacted through feedback loops, sequence of interaction between actor. The non-linearity caused by these loops and feedbacks is one of the main characteristics of complex adaptive systems (CAS), a type of systems with the ability to adapt or change their structure that has been extensively explored in the field of complex systems [Etzkowitz and Leydesdorff 2000, Holland 2012, Ladyman et al. 2013]. CAS are systems with a large number of components, often called agents that interact to adapt and learn. This interaction, usually non-linear, generates an set of features of this class of systems eg. non-linearity, feedback and emergence, which can be understood as an increase in complexity [Ladyman et al. 2013].

Therefore, this leads us to believe that the Innovation System formed by the oil and gas $(\mathrm{O} \& \mathrm{G})$ industry in Brazil shall be studied and modeled from the perspective of a complex adaptive system in order to capture the essential characteristics of its dynamics.

\section{Context and Research Problem}

Brazilian Law 9478/98 establishes, the compulsory investment in research and development (R\&D) activities, stimulating the technological development of the O\&G industry, adopting an national development model similar to the Norwegian case [Hatakenaka et al. 2011]. In this regulatory model, O\&G producers reinforced the historical relationship among Universities, Government and Industry [Turchi and De Negri 2013].

The policy set up that O\&G Companies are obliged to invest a fraction of $1 \%$ of gross revenue from specially qualified Brazilian O\&G fields in their own facilities, universities, technology-based companies or startups. Nowadays, Petrobras, the largest oil producer in Brazil, is currently responsible for $85 \%$ of the investment foreseen for the clause [Fig 2]. The new regulatory scenario set up a new configuration of the actors in the system and is expected an R\&D investment boost with the start of production of the new giant fields in the Pre-Salt and Libra areas, expected from 2019.

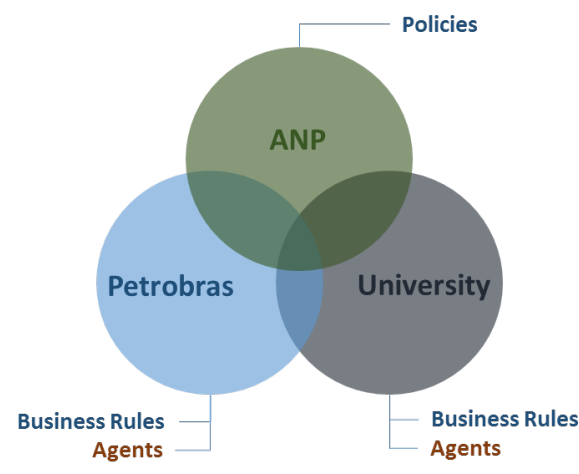

Figure 1. The Brazilian UGI Innovation System

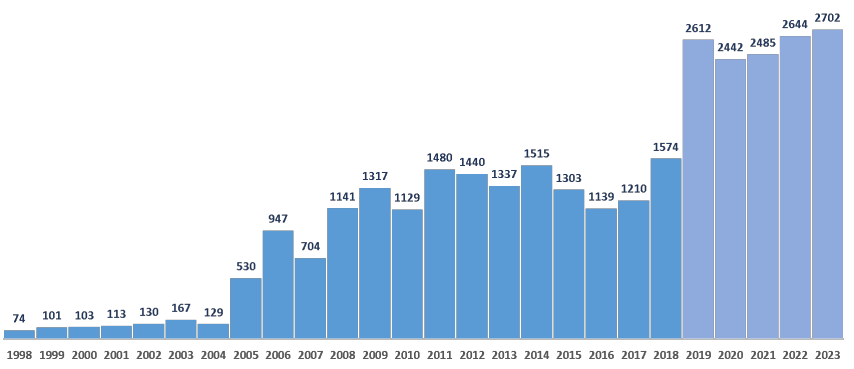

Figure 2. Investment from 1998 to 2013 (R\$M)

At the heart of this innovation system is the University-Industry collaboration and the information flows between researchers from $O \& G$ companies and professors from the universities who are responsible for the $R \& D$ activities. 
In this context, the aims of this research project is to understand impacts of the complex social dynamics of cooperation between researchers and professors in Brazilian O\&G Innovation System through the CAS lens, in order to understand and measure the possible effects of the investment policy adopted by Brazilian government.

\section{Literature Review}

Universities play a crucial role in society as producers and transmitters of knowledge and provide an important mechanism for generating technological spillovers. This aim is achieved fundamentally through R\&D projects, teaching, commercialization of technologies and services, provision of technical advice and dissemination of knowledge in UGI systems. In addition universities carry out more and more business functions, creating innovative small business and thus becoming a relevant part of socioeconomic development [Martin and Scott 2000].

In addition, University-industry collaboration is a relevant economic driver for economic development as presented through knowledge and technology transfer by cross-different institutional boundaries [Etzkowitz and Leydesdorff 2000]. Managing these boundaries could be one of the central challenges, because the collaboration between business practitioners and academic researchers is a high-level complex process that encompasses cooperation, teamwork and coordination across organizations [Bedwell et al. 2012, Rajalo and Vadi 2017].

\section{Methods}

The study of complex adaptive systems, from cells to societies, is a study of the interplay among processes operating at diverse scales of space, time and organizational complexity. Two complex systems modeling techniques - agent-based modeling (ABM), and network analysis - are presented to illustrate how each method can be used to address the research project.

ABM is a methodology used to build models of systems that are made up by individual units which repeatedly interact among themselves and/or with their environment. It was one of the primary methodologies that has arisen from complex systems research [Wilensky and Rand 2015].

The agent-based modelling has its fundamentals in a bottom-up perspective describing a system from the perspective of its constituent units, i.e. the agents. In $\mathrm{ABM}$, a system is modeled as a collection of autonomous decision-making agents which individually assesses its situation and makes decisions on the basis of a set of rules [Bonabeau 2002]. Repetitive interactions between agents through simulations are a feature of $\mathrm{ABM}$ in order to explore dynamics out of the reach of pure mathematical methods. Building the model from the bottom-up means letting complex macroscopic systems emerge from the interactions of microscopic entities [Axelrod and Tesfatsion 2006].

In this project, the $\mathrm{ABM}$ of the dynamics among researchers-professors will be codified and simulated in NetLogo, a multi-agent programming language and modeling environment for simulating complex phenomena [Wilensky and Rand 2015]. The results of the NetLogo simulations will be analyzed from a network background as the researcher-professor social dynamics can be interpreted within the frame of network analysis. 
Complex networks are the backbone of complex systems as each complex system can be viewed as a network of interactions among numerous network elements. The dynamic nature of a network is considered one of the keys to understand complexity and the nature of complex innovation systems [Mittal 2013, Dougherty 2017].

As a network, we describe a set of objects, or nodes, and a set of connections, or links, between the objects. In mathematics, graph theory is used to analyze networks in terms of nodes and connections, but the seemingly simple technique of displaying networks as nodes linked by lines, turns out to be a sophisticated tool for disclosing the properties and patterns of networks. Approaching systems as networks is a fashion to an overall understanding of the structure of the system, since concepts and conceptual connections qualify as objects and links.

\subsection{First Experimental Design}

Wilensky and Rand [Wilensky and Rand 2015] present a guide to design the model based on the Driving Question of the model. This question is intended to focus on a phenomenon for which would build an ABM model [tab.1].

\begin{tabular}{ll} 
Model Issue & \\
\hline \hline Driving Question & $\begin{array}{l}\text { How the relationship dynamics among university professors and company } \\
\text { researchers influence the formation of a portfolio of R\&D projects in the Brazilian } \\
\text { Oil \& Gas Innovation System }\end{array}$ \\
& University Professors (mobile agent), Company Researchers (mobile agent), Large \\
Agent Types & Project (connecting agent), Small Project (connecting agent)
\end{tabular}

Figure 3. Guide to design the ABM Models

The model will be based on a continuous social search space where agents where professors and researchers look for each other in order to conduct research projects based on the parameters. This world holds a bounded topology, in other words, agents are not allowed to move beyond the edges of the world. The main reason for this choice is the possibility to explore the network created by the links among the agents.

Thus, the dynamics of the model begins with the distribution of the annual R\&D budget among the company's researchers. After this distribution, they begin a search 
for cooperation at social $R \& D$ space, in random movements, by the professors of the Universities.

If the researcher find a professor within their radius of attraction that meets the criteria set up for affinity and trust, the researcher will create a link with the professor in order to develop the R\&D project. The sort of R\&D project, larger or smaller, also depends on the trust and affinity levels. Each type of project possess a corresponding average cost, which means that the researcher's available investment value and the professor's investment absorption capacity are updated after the link be established. In addition to the budget restrictions, each researcher and professor is also constrained on the number of projects each one can cooperate.

In this framework, the set of behavioral rules will be designed based on direct observations of researchers and professors dynamics. Expert judgment - discussions in forums (seminars, conferences) with the agents - will be utilized to validate the set of rules, as validation of $\mathrm{ABM}$ of social processes inevitably assumes a degree of arbitrariness and subjective judgment [Bonabeau 2002].

\section{Research Plan}

Presently, the model is being coded and adjusted in NetLogo. After the codification, will take place the simulation step. As the dynamics of the model is based on the strategic choices of the agents, the agents' behavior whether or not to do a project can be understood within the context of evolutionary game theory (EGT), which can be a way to explore other agents strategies that may impact their behavior.

\begin{tabular}{|c|c|}
\hline Rules Validation & Experts validation of the rules \\
\hline NetLogo Programing & Coding and model adjustments \\
\hline Simulations & First tests on the model to analyze agent behavior \\
\hline Agent Behavior Analysis & $\begin{array}{l}\text { Exploratory analysis of new behavior strategies for } \\
\text { model improvement }\end{array}$ \\
\hline Network Analysis & Analysis of the structure generated by the model \\
\hline
\end{tabular}

Figure 4. Research Plan

As a resume, is expected that a model with simple rules that describe the behavior of the agents responsible for the dynamics of the Brazilian Oil \& Gas innovation system contribute to the understanding of the impact of the policies carried out by the Brazilian Government. 


\section{References}

Axelrod, R. and Tesfatsion, L. (2006). A guide for newcomers to agent-based modeling in the social sciences. Handbook of computational economics, 2:1647-1659.

Bedwell, W. L., Wildman, J. L., DiazGranados, D., Salazar, M., Kramer, W. S., and Salas, E. (2012). Collaboration at work: An integrative multilevel conceptualization. Human Resource Management Review, 22(2):128-145.

Bonabeau, E. (2002). Agent-based modeling: Methods and techniques for simulating human systems. Arthur M. Sackler Colloquium of the National Academy of Sciences, 2:7280-7287.

Dougherty, D. (2017). Organizing for innovation in complex innovation systems. Innovation: Management, Policy and Practice, 19(1):11-15.

Etzkowitz, H. and Leydesdorff, L. (2000). The dynamics of innovation: from national systems and "mode 2" to a triple helix of university-industry-government relations. Research policy, 29(2):109-123.

Hatakenaka, S., Westnes, P., Gjelsvik, M., and Lester, R. (2011). The regional dynamics of innovation: A comparative study of oil and gas industry development in stavanger and aberdeen. International Journal of Innovation and Regional Development, 3(34):305-323.

Holland, J. H. (2012). Signals and boundaries: Building blocks for complex adaptive systems. MIT Press.

Ladyman, J., Lambert, J., and Wiesner, K. (2013). What is a complex system? European Journal for Philosophy of Science, 3(1):33-67.

Martin, S. and Scott, J. T. (2000). The nature of innovation market failure and the design of public support for private innovation. Research policy, 29(4-5):437-447.

Mittal, S. (2013). Emergence in stigmergic and complex adaptive systems: A formal discrete event systems perspective. Cognitive Systems Research, 21:22-39.

Nelson, R. R. and Winter, S. G. (2014). Towards an Evolutionary Theory of Economic Change. Harvard University Press.

Rajalo, S. and Vadi, M. (2017). University-industry innovation collaboration: Reconceptualization. Technovation, 62:42-54.

Ranga, M. and Etzkowitz, H. (2015). Triple helix systems: an analytical framework for innovation policy and practice in the knowledge society. In Entrepreneurship and knowledge exchange, pages 117-158. Routledge.

Turchi, L. and De Negri, J. A. (2013). Impactos tecnológicos das parcerias da petrobras com universidades e centros de pesquisa. Impactos tecnológicos das parcerias da Petrobrás com Universidades, centros de pesquisa e firmas brasileiras.

Wilensky, U. and Rand, W. (2015). An introduction to agent-based modeling: Modeling Natural, Social, and Engineered Complex Systems with NetLogo. The MIT Press. 